\section{Hersiening van die Statistiekwoordeboek}

Die bestaande Statistiekwoordeboek is deur wyle prof. B. de Loor, eertydse hoof van die Departement Statistiek aan die Universiieit van Pretoria, opgestel in opdrag van Die Suid-Afrikaanse Akademie vir Wetenskap en Kuns. Dit het in 1961 verskyn en is sedertdien nog nooit hersien nie. Met die geweldige ontwikkeling van die vakwetenskap Statistiek in die afgelope dekades en die gepaardgaande uitbouing van die vakterminologie, is die bestaande woordeboek totaal verouderd. Intensiewe hersiening het dringend noodsaaklik geword. Prof. D.J. Stoker, tans Direkteur van die Instituut vir Statistiese Navorsing van die R.G.N., het dan ook enkele jare gelede met die aanvoorwerk begin, maar moes die taak weens 'n druk werksprogram laat vaar.

Op versoek van Die Suid-Afrikaanse Akademie vir Wetenskap en Kuns het prof. H.S. Schoeman, tans hoof van die Departement Statistiek aan die Universiteit van Pretoria, in 1980 die taak van prof. Stoker oorgeneem. Met behulp van 'n toekenning van die R.G.N. is mev. J.M. Steyn as navorsingsassistente vir die projek aangestel. 'n Paneel van tien medewerkers is ook saamgestel, te wete prof. N.F. Laubscher (U.P.E.), prof. D.G. Nel (U.O.V.S.), prof. D.M. Schultz (UNISA), prof. H.S. Steyn (jr.) (P.U. vir C.H.O.), prof. D.J. Stoker (R.G.N.), prof. A.J.B. Wiid (R.A.U.), dr. N.J. le Roux (U.S.), dr. E.L. Raath (W.N.N.R.), dr. F.L. Vivier (Departement van Statistiek) en mnr. R. Gonin (M.N.R.).

Die taak het in Januarie 1981 in alle erns 'n aanvang geneem. Die werksprosedure bestaan daaruit dat daar allereers ' $n$ volledige Engelse lys van terme opgestel word met 'n proefvertaling in Afrikaans. Hierdie lys word dan aan al die medewerkers gestuur vir kommentaar en aanvulling. Nadat hierdie kommentaar terug ontvang en verwerk is, word die woordelys op die rekenaar geplaas. Deur middel van 'n gerekenariseerde woordeboekstelsel wat by die W.N.N.R. ontwikkel is, word die omskakeling na AfrikaansEngels gedoen, waarna die rekenaar die volledige Engels-Afrikaanse en Afrikaans-Engelse woordelyste uitdruk. Nadat hierdie lyste weer op 'n werksessie deur die medewerkers behandel en vakkundig goedgekeur is, sal dit as geheel finaal taalkundig versorg en gepubliseer word.

Die hele projek staan onder die toesig van 'n Advieskomitee wat saamgestel is uit prof. H.S. Steyn (sr.) wat namens Die S.A. Akademie vir Wetenskap en Kuns ook as voorsitter optree, dr. A. Strasheim namens die Afdeling Wis- en Natuurkunde van Die S.A. Akademie vir Wetenskap en Kuns, prof. D.J. Stoker namens die R.G.N., mnr. D.L.E. Laubscher namens die Vaktaalburo van die Departement van Nasionale Opvoeding en prof. H.S. Schoeman van die Universiteit van Pretoria as projekleier. Mev.
J.M. Steyn tree op as sekretaresse van die Advieskomitee.

Baie goeie vordering is reeds met die projek gemaak. Na agtien maande is die woordelyste van die eerste agt alfabetletters al op die rekenaar geplaas en afgehandel terwyl kommentaarlyste van die volgende tien letters ook reeds uitgestuur is. Daar word gepoog om die taak vroeg in 1984 te voltooi.

\section{Wiskundewoordeboek}

Die Wiskundewoordeboek (Engels-Afrikaans en Afrikaans-Engels) het in 1971 verskyn as resultaat van 'n taak wat in 1924 deur prof. W.F.C. Arndt op eie inisiatief aangepak is, en langs die pad verder baie medewerkers bygekry het. Dit is saamgestel met behulp van die Vaktaalburo en uitgegee deur Die Suid-Afrikaanse Akademie vir Wetenskap en Kuns.

$\mathrm{Na}$ die verskyning van die Wiskundewoordeboek het daar in Tydskrif vir Natuurwetenskappe 'n resensie deur prof. G.G. Cillié verskyn wat propvol stimulerende voorstelle is. Daarin het hy onder andere ook melding gemaak van die bestaan van 'n streekterminologie. As gevolg van die vroeër relatief min kommunikasie tussen Afrikaanse wiskundiges, het daar in bepaalde gevalle verskillende terme in die Noorde en die Suide ingeburger geraak. Dit sal interessant wees om te weet in welke mate die voorgestelde vertalings landswyd inslag gevind het.

Prof. L.C. Eksteen het as taalkundige in Tydskrif vir Geesteswetenskappe onder andere aangedui in watter opsigte die Redaksie nie konsekwent was nie, en hy het dit met ,,genadelose" deskundigheid gedoen.

Van verskeie individue en instansies is verdere kommentaar ontvang. Veral is daar baie uitgewei oor die verskil tussen getal en aantal.

Woordeboekmaak is 'n werk met 'n begin maar sonder 'n einde, veral as dit om Afrikaanse vakterminologie draai. Die Akademie het enkele jare gelede sy Afdeling Wis- en Natuurkunde versoek om te begin werk aan 'n hersiene uitgawe van die Wiskundewoordeboek. Prof. P.J. Zietsman het opdrag gekry om die projek aan die gang te sit, maar daar is nie veel vordering gemaak nie. Nou is daarin geslaag om 'n toekenning van die R.G.N. te kry wat dit moontlik maak om deeltydse assistensie te bekom. Dit behoort die tempo van die projek aansienlik te versnel.

Belangstellende individue en instansies sal in die nabye toekoms gevra word om medewerkers te word deur kommentaar te lewer op voorgestelde vertalings. Intussen ontvang die projekleier, prof. P.J. Zietsman, Universiteit van Pretoria, graag kommentaar oor of byvoegings tot die Woordeboek wat miskien met die verloop van tyd versamel is. 